\title{
NOTE ON A NEW SPOTTED BAMBOO "YÔRAKU- MONTIKU" CAUSED BY Lembosia tikusiensis n. sp.
}

\author{
Zyun HIDAKA \\ (Phytopathological Laborațory, Faculty of Agriculture, \\ Kȳ̄syū Imperial University.)
}

(日高醇：Lembosia tikusiensis の寄生による新斑竹““娶珞絞竹”)

Received Febriary 2S, 1940.

\section{INTRODUCTION}

In June 1937, the writer found at Mt. Hôman near Hukuoka city several, beautiful spotted bamboo staiks of Phyllostachys nigra MUNRO var. Henonis STAPF. And in February 1939, the same spotted bamboos were found at Mt. Hiko being sold as souvenir sticks made at Yunomae at the foot of Mt. Itihusa in Prov. Higo. The production is great and it is localized at the foot of Mt. Itihusa which extends over both Prov. Hyuga and Higo. It was ascertain$\mathrm{cd}$ that these spots were formed on the bamboo stalks when they were affected by a fungus new to science which the writer named Lcmbosia tikusiensis and called the spotted bamboo "Yôrakumontiku".

The writer wishes to dedicate this paper in rememberance of late Professor K. NAKATA and expresses his sincere gratitude to Assistant Professor H. YOSHII for his kind directions and valuable suggestions during the course of the investigation.

\section{THE SPOTS}

The culms of Phyllostachys nigra MUNRO var. Henonis STAPF affected by the fungus indicate at first the minute dark brown spots, and then the latter swell in size gradually, but never over the node. The spots form the indifinite concentric rings; the centre and edge of them are dark brown in colour (Bone Brown, Rdg. P1. XL), while the other parts . show light brown (Pinkish Buff, Rdg. P1. XXIX). Frequently the spots are entirely coated with mortar-like substance, but. when the oils in the culm are drown out over the fire and rubbed off, the mortar-like matter 
fades away from the spots, and then turn into the colour described above. Later, the spots become elliptical with irregtuarly wavedmargins, and the size of them reaches about $12 \times 6 \mathrm{~mm}$. The spots were generally on the stalks between the third and tenth node above the earth,—- between 10 to $180 \mathrm{~cm}$ in height. Under suitable conditions they were on the branches and stalks in higher parts than stated above and also rarely on the stalks in the soil which are not subterranean shoots. The writer could not find the spots on the leaf. The part of the culm forming spots may be affected by environmental conditions; on the sunny side of the ctrlm, the spots tend to be few and small. Mostly, the spots were found on the culms of more than two years old, especially on those of which upper parts were weakened or killed by various causes. The spotted bamboos are found in the extremely crowded growths of Pliyllostackys nigra MUNRO var. Henonis STAPF, or in the bamboo. groves made gloomy in the daytime by mixtures of other broad leaf trees which compose about 30 per cent. of the grove. In either case, there was always a very high humidity created by small springs or running waters under the grove both at Mt. Hôman and at the foot of Mt. Itihusa. The other bamboos such as Phyllostachys reticulata, Pleioblastus Simonii, Pseudosasa japonica, and Shibataca Kumasaka growing near the spotted bamboos were found to be indifferent to the funcus. The spotted' bamboo stalks may be excellent materials for industrial products, because of the handsomeness of the Lembosia spots.

\section{THE CAUSAL FUNGUS}

The perithecia are found on the surface of the spots. They appear at first as small tawny black specks, scarcely observab!e to naked eyes. Infructescence they attain obiong or linear sometimes radial shield shapes and almost black in colour, measuring 153$1064 \times 82-216 \mu$. The linearfis sures, or ostiols are observed along the ridge of perithecia. Numerous asci are observed in a perithecium; each of them.contains eight spores. The asci are hyaline, smooth, ovoid or piriform in shape, and measure $32-44 \times 16-19 \mu$ in size. The ascospore is slightly constricted at the septum. The ascospores are at first hyaline, but later become light brown in colour, and are 16-18 $\times 7-9 \mu$ in size. The paraphyses are numerous, hyaline, filiform with swollen apices, longer than the asci, and measure about $44 \mu$ in length. The aerial mycelinm $2.5-3 \mu$ in which is dark brown in colour, superficial, branching and radiating irregttlarly. The hyphopodia are brown, round or irregular 
in shape, measuring $14-26 \mu$ in diam. The Latin description of the fungus is as follows :

Lembosia tikusiensis n. $\mathrm{sp}$.

Culmicola. Myceliis superficialibus, brunneis, ramosis, $2.5-3 \mu$ crasis ; hyphopodiis sparsis, concoloribus, $14-26 \mu$ diam.; peritheciis superficialibus, elongatis, interdum radiatis, primum brunneis, demum nigro-brunneis, rigidis, $153-1064 \times 82-216 \mu$ diam.; ascis ovoideis, octosporis, $32-44 \times 16-19 \mu$, paraphysatis ; sporidiis brunneis laevibus, oblongo-ovoideis, constricto-1-septatis, $16-18 \times 7-9 \mu$; paraphysibus filiformibus, numerosis, hyalinis, apice incrassätis, asci ssuperantibus.

Hab. ad culmos vivis Phyllostachidis nigrae, Prov. Tikusi, Japoniae.

\section{REFERENCES}

Theissen, F.: Lembosia-Studien. Ann. Myc., Vol. XI, no. 6, s. 427-46r, 1913. TheIssen, F. und Sydow, H.: Synoptische Tafeln. Ann. Myc., Vol. XV, no. 6, s. 389-491, 1917.

\section{摘 要}

1937 年 6 月輻岡市近郊の寶滿山にハチォクの新斑竹を探集し, 又 1939 年 2 月 豉前國英产山の土産物店で英彥山登山記念の杖の中に同樣の紋のある敀の杖を

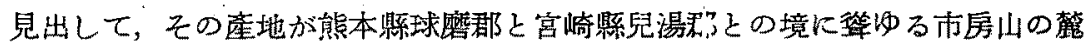
一带の廣い籁圍である事が判つた。

該斑竹は未知の菌の笴生によるものであり，又斑竹としての名稱も與へられ て居䄈かつたので，茲に菌名をLembosia tikusiensis として九州の古名筑紫國 の名に因み，斑竹名を筞珞紋竹と命名した。

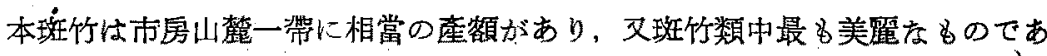
つて竹種がハチクであるから杖その他の工㙯品として用途は廣いであらろ。 
第 3 藏版

Plate III

Fig. 1

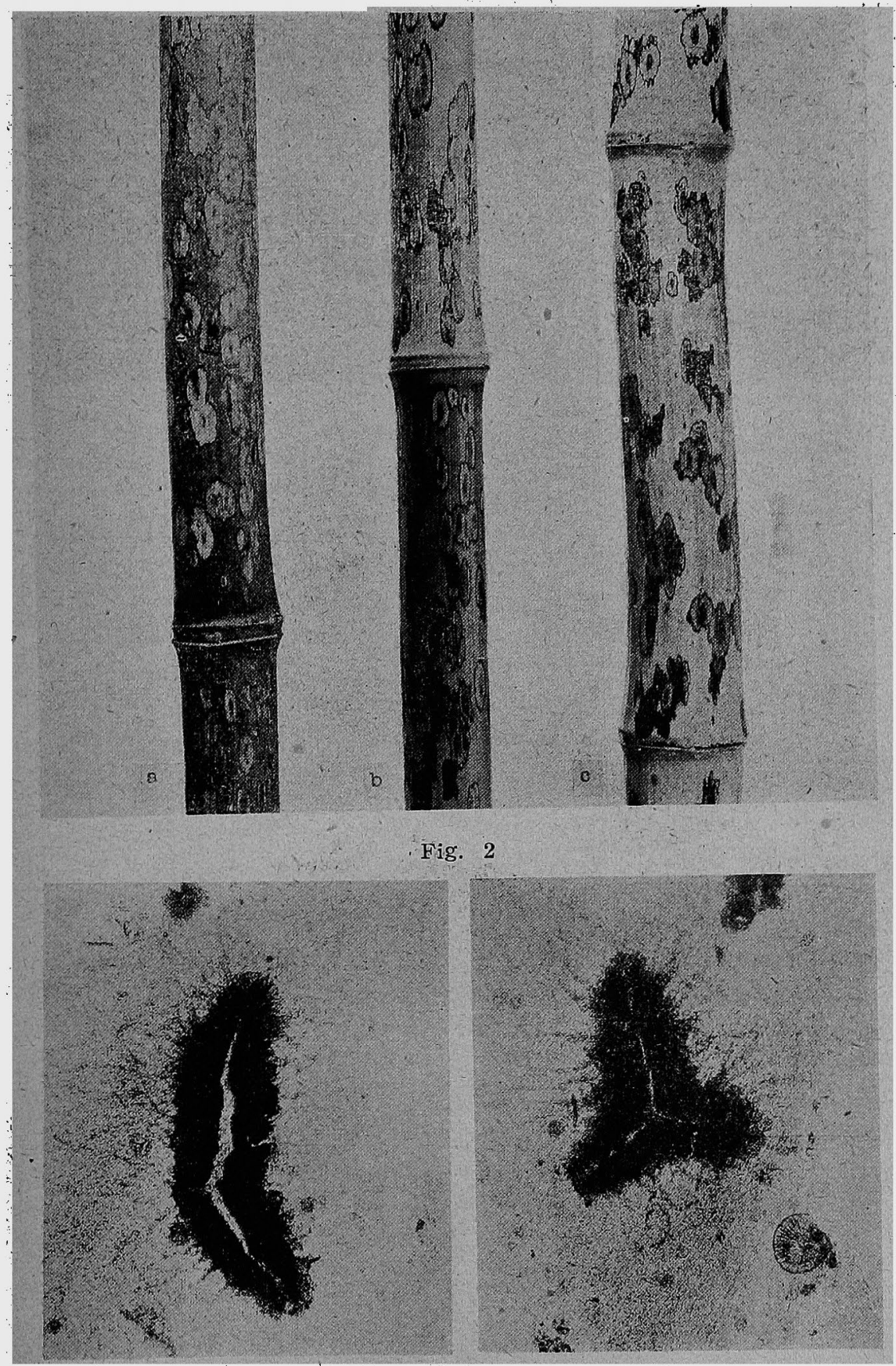




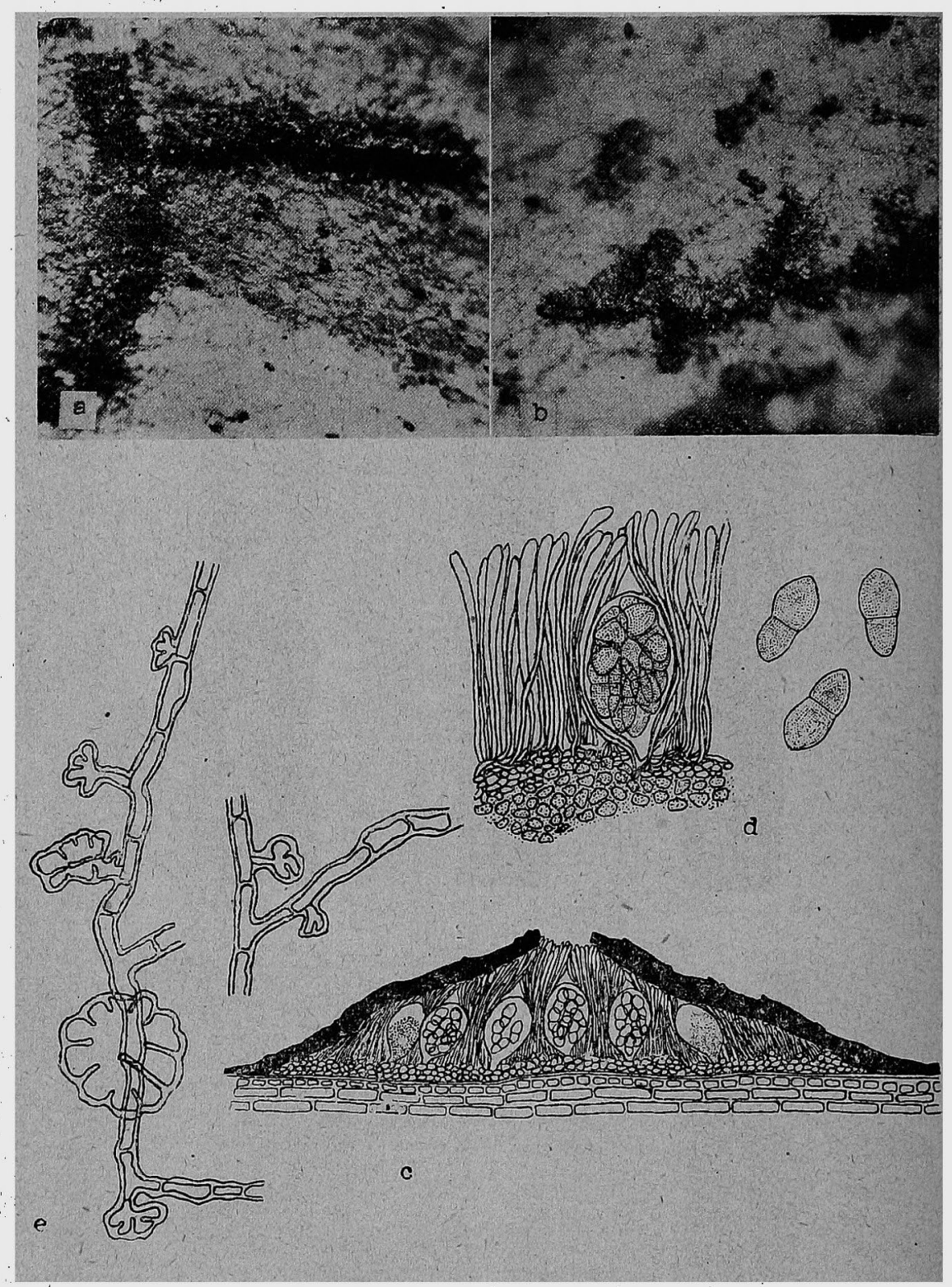




\section{Explanation of plate}

Plate III

Fig. 1. The spotted bámboo stalks "Yôraku-montiku". a: Natural state.

$\mathrm{b}, \mathrm{c}$ : Oils drawn out and polished.

Fig. 2.

a, b: Matúre and immature perithecia of Lembosia tikusiensis. Plate IV

a, b: Mature perihecia of Lembosia tikusiensis under ultra-pak.

c: A cross-section of the perithecium of Lembosia tikusicnsis.

d: Ascus, paraphyses and ascospores of Lembosia tikutiensis.

e: Hyphopodia and mycelia of Lembosia tikusientsis. 